requiring nations to conserve and protect the marine environment', and urged President Reagan to 'sign the treaty and seek its ratification'. In the same resolution the Sierra Club also called upon all nations to protect the marine environment, as urged by the World Conservation Strategy.*

ANITA YURCHYSHYN, Chairman

Sierra Club International Marine Environment Committee International Earthcare Center

228 East 45 Street

New York, NY 10017, USA.

\section{The Woodlands Conference and the Mitchell Prize Competition}

The Woodlands Conference, Inc., was founded in 1975 as a non-profit educational institution for the purpose of public education concerning the issues of sustainable societies. The term 'sustainable societies' means, in this context, societies in which social and economic progress has been made that is consistent with the world's finite resource-base; in other words, societies which are not necessarily dependent on continued growth in energyuse, population, materials consumption, and industrial output.

The Conference as a whole is engaged in a 10-15years' series of biennial conferences, the next of which, entitled 'The Future and the Private Sector', is to be held during 7-10 November 1982 near Houston, Texas. The conference will consider the major factors of production in the context of sustainable societies over the next two decades, and will involve several hundred business, academic, governmental, and non-governmental, leaders from around the world.

Associated with each biennial event is the Mitchell Prize competition for scholarly papers on the means and possibilities of transition to sustainable societies. The theme for this year's $\$ 100,000$ competition is 'Future Roles for the Private Sector'. The Woodlands Conference, Inc., also provides speakers occasionally for public events, and publishes a quarterly newsletter Sustainable Societies.

The Woodlands Conference, Inc., receives most of its financing from the Mitchell Energy and Development Corp, and from George and Cynthia Mitchell who sponsor the Mitchell Prize. Dr Gerald O. Barney, previously Study Director of The Global 2000 Report to the President, is executive director of the Woodlands Conference. For further information write: The Woodlands Conference, Inc., PO Box 9663, Arlington, Virginia 22209, USA.

\section{Study to Understand how Earthquakes Originate and Behave}

The United States and India are moving swiftly to install a network of instruments to measure earthquake

\footnotetext{
*Nevertheless on 9 July 1982 President Reagan announced that the United States would not sign the Treaty; for although they recognized that it contains 'many positive and very significant accomplishments' and that 'most other provisions are consistent with US interests', the Administration rejected the deep seabed mining portions of the text.-Ed.
}

ground-motion in northern India, which is one of the world's areas where large earthquakes are 'common'.* Fifty accelerographs-instruments that measure strong ground-motion-will be installed in the initial stage of the two-years' project in the Himalayan region. The network could eventually be increased to 200 instruments.

The US National Science Foundation is coordinating the project with the Indian Department of Science and Technology, through the University of Roorkee.

The Indian array, one of a series of such networks that are planned throughout the world, is designed to help to provide a comprehensive set of strong ground-motion data from near the centre of destructive earthquakes. The data are urgently needed by earthquake engineers whose research has been handicapped by a lack of such information. Specifically, the project will gather data on how earthquakes originate, how ground-motion is transmitted, and how it changes in intensity.

C. Eric Lindvall, of Lindvall, Richter \& Associates, an earthquake sciences and engineering firm in Los Angeles, is principal investigator for the US. Lindvall stated that in 1978 an international group of engineers and scientists identified 28 regions of the Earth as likely to have large earthquakes in the 'next decade or so'. These were considered good locations for installing the strong-motion instruments. Four of these 28 sites had experienced a strong earthquake in recent years, he said, which 'makes it urgent that this area should be instrumented promptly and adequately so as to record the strong groundmotions which would be generated by the probable large earthquake in the region'.

In the past century there have been several Himalayan earthquakes that can be counted as among the largest in history. Lindvall said: 'The occurrence of a large earthquake in the region can thus be expected in the present or coming decades.'

The advantages of joint research to both the US and India were pointed out by Lindvall: 'For the US... the increase in potential availability of data concerning large earthquakes from a highly seismic region would represent a very significant addition to the capabilities of existing US networks. For India, the experience gained in operation of large field arrays and instrumentation and in the large-scale data processing requirements of such arrays would be most valuable.'

A committee that will work with Lindvall includes Dr Anil K. Chopra of the University of California-Berkeley; Dr Donald E. Hudson, University of Southern California, and Dr Haresh C. Shah of Stanford University. The Himalayan area was designated as the site for the array after two meetings: the International Workshop on Strong-Motion Earthquake Instrument Arrays, held in Hawaii in May, 1978, and the Indo-US Workshop on Natural Disaster Mitigation Research in New Delhi in December, 1978.

RALPH KAZARIAN
National Science Foundation
1800 G Street
Washington
DC 20550, USA.

* Others of course include the Tokyo and San Francisco areas respectively on the western and eastern Pacific Ocean coasts, and, perhaps still more alarmingly, the New Madrid area in the 'middle eastern' United States-see the 'new nightmare' account in The Economist, 4 September 1982, pp. 93-4, with map indicating also nuclear power-plants.-Ed. 